\title{
Association between Chagas disease and changes in the optic nerve and retinal nerve fiber layer
}

\author{
Associação entre doença de Chagas e alterações do nervo óptico e \\ camada de fibras nervosas
}

\author{
Flávia da Silva Villas-Bôas', Alexandre Campelo Ramiro', Thaís de Santana Machado Martins', Wilker Malta de Sousa', \\ Marcia Maria Noya-Rabelo2,3, João Antônio Prata Jr.4,5, Luiz Cláudio Lemos Correia 2,3 \\ 1. Instituto Brasileiro de Oftalmologia e Prevenção da Cegueira, Salvador, BA, Brazil. \\ 2. Escola Bahiana de Medicina e Saúde Pública, Salvador, BA, Brazil. \\ 3. Hospital São Rafael, Salvador, BA, Brazil. \\ 4. Departamento de Oftalmologia, Universidade Federal do Triângulo Mineiro, Uberaba, MG, Brazil. \\ 5. Departamento de Oftalmologia, Universidade Federal de São Paulo, São Paulo, SP, Brazil.
}

RESUMO | Objetivo: Testar a hipótese de que a doença de Chagas predispõe a alterações no nervo óptico e camada de fibras nervosas peripapilar. Métodos: Foi realizado um estudo transversal com 41 pacientes diagnosticados com doença de Chagas e 41 controles, pareados por sexo e idade. Os pacientes foram submetidos a exames oftalmológicos, incluindo medida da pressão intraocular, avaliação do nervo óptico e camada de fibras nervosas através de retinografia, tomografia de coerência óptica e perimetria automatizada padrão. Resultados: Todos os pacientes com doença de Chagas apresentavam estudo cardiológico recente; 15 pacientes (36,6\%) apresentavam insuficiência cardíaca; 14 (34,1\%) forma cardíaca sem disfunção de ventrículo esquerdo e 12 (29,3\%), forma indeterminada. Alterações do nervo óptico/camada de fibras nervosas foram observadas em 24 pacientes $(58,5 \%)$ do grupo com doença de Chagas e 07 controles $(17,1 \%)$ $(p \leq 0,01)$. Dentre estas, palidez do nervo óptico, alterações do nervo óptico sugestivas de glaucoma, entalhe, hemorragia peripapilar e defeito da camada de fibras localizado foram detectados. As alterações foram mais proeminentes nos pacientes com doença de Chagas e insuficiência cardíaca (11 pacientes) embora também ocorressem naqueles com doença de Chagas sem disfunção de ventrículo esquerdo (7 pacientes) e com forma indeterminada (6 pacientes). A tomografia de

Submitted for publication: January 10, 2018 Accepted for publication: August 1, 2018

Funding: No specific financial support was available for this study. Disclosure of potential conflicts of interest: None of the authors have any potential conflicts of interest to disclose.

Corresponding author: Flávia S. Villas Bôas.

Av. Princesa Leopoldina, 19/402 - Salvador- Bahia - 40150-080 - Brazil

E-mail: f.villasboas.fvb@gmail.com

Approved by the following research ethics committee: Hospital São Rafael Plataforma Brasil (CAAE: 31156514.8.0000.0048, parecer 731.162). coerência óptica mostrou que a média da espessura da camada de fibras nervosas da retina mediu $89 \pm 9,7 \mu \mathrm{m}$ ), e a média da espessura da camada de fibras nervosas superior e inferior mediu $109 \pm 17,5$ e $113 \pm 16,8 \mu \mathrm{m}$, respectivamente, foi menor em pacientes com doença de Chagas. Nos controles, esses valores foram de $94 \pm 10,6 \mu \mathrm{m}(p=0,02) ; 117 \pm 18,1(p=0,04)$ e 122 $\pm 18,4 \mu \mathrm{m}(p=0,03)$. Conclusão: Alterações do nervo óptico/ camada de fibras nervosas da retina foram mais prevalentes nos pacientes com doença de Chagas.

Descritores: Doença de Chagas, Oftalmopatias; Nervo óptico; Insuficiência cardíaca

ABSTRACT | Purpose: To test the hypothesis that Chagas disease predisposes to optic nerve and retinal nerve fiber layer alterations. Methods: We conducted a cross-sectional study including 41 patients diagnosed with Chagas disease and 41 controls, paired by sex and age. The patients underwent ophthalmologic examinations, including intraocular pressure measurements, optic nerve and retinal nerve fiber layer screening with retinography, optical coherence tomography, and standard automated perimetry. Results: All of the patients with Chagas disease had a recent cardiologic study; 15 (36.6\%) had heart failure, 14 (34.1\%) had cardiac form without left ventricular dysfunction, and 12 (29.3\%) had indeterminate form. Optic nerve/retinal nerve fiber layer alterations were observed in 24 patients $(58.5 \%)$ in the Chagas disease group and 7 controls $(17.1 \%)(p \leq 0.01)$. Among these, optic nerve pallor, optic nerve alterations suggestive of glaucoma, notch, peripapillary hemorrhage, and localized retinal nerve fiber layer defect were detected. Alterations were more prominent in patients with Chagas disease and heart failure (11 patients), although they also occurred in those with Chagas disease without left ventricular dysfunction (7 patients) and those with indeterminate form (6 patients). Optical coherence tomography showed that themean of the average retinal nerve fiber layer thickness measured 
$89 \pm 9.7 \mu \mathrm{m}$, and the mean of retinal nerve fiber layer superior and inferior thickness measured $109 \pm 17.5$ and $113 \pm 16.8 \mu \mathrm{m}$, respectively were lower in patients with Chagas disease. In controls, these values were $94 \pm 10.6(p=0.02) ; 117 \pm 18.1$ $(p=0.04)$, and $122 \pm 18.4 \mu \mathrm{m}(p=0.03)$. Conclusion: Changes in optic nerve/ retinal nerve fiber layer were more prevalent in patients with Chagas disease.

Keywords: Chagas disease; Eye disease; Optic nerve; Heart failure

\section{INTRODUCTION}

Discovered in 1909 by the Brazilian physician and researcher Carlos Chagas, Chagas disease is a systemic parasitic infection caused by the protozoan Trypanosoma cruzi. with a chronic phase following an acute phase ${ }^{(1)}$. Chagas disease is recognized by the World Health Organization as one of the 13 most neglected tropical diseases in the world, and it remains a social and economic problem in several Latin American countries ${ }^{(2)}$.

Few studies have evaluated the ocular repercussions of Chagas disease, although Romaña's sign was one of the first acute phase manifestations to be reported ${ }^{(3)}$. Conjunctivitis, keratitis, scleritis, iridocyclitis, and choroiditis anterior and posterior uveitis have been described in congenital Chagas disease with remission after treatment of the disease ${ }^{(4)}$.

Autonomic nervous system (ANS) involvement, characteristic of the chronic phase of Chagas disease, was reported in studies showing abnormal pupillary responses to diluted pilocarpine and intraocular pressure (IOP) postural variability ${ }^{(5,6)}$. In the chronic phase of the disease, chronic heart failure (CHF) occurs in some chagasic patients and may be involved in alterations of the optic nerve $(\mathrm{ON})$ and retinal nerve fiber layer $(\mathrm{RNFL})^{(7)}$.

The present study attempted to identify changes in ON and RNFL in patients with chronic Chagas disease. The systemic disturbances of the disease, whether related to inflammatory, vascular, or ASN dysfunction, are associated with ON and RNFL and may be related to lesion segmentation.

\section{METHODS}

We conducted a cross-sectional study at the Brazilian Institute of Ophthalmology and Blindness Prevention (IBOPC) including individuals diagnosed with Chagas disease who were treated at the Chagas outpatient clinic at São Rafael Hospital, Salvador, Bahia, Brazil. Noncardiopathic volunteers matched by sex and age (with a maximum difference of \pm 2 years) were included as the control group. IBOPC employees were recruited as volunteers to perform periodic exams with screening for cardiopathies. When matching criteria could not be achieved, employees' relatives were recruited provided there was no consanguinity among the participants. Relatives were questioned regarding follow-up with a cardiologist in the last 6 months. The study was approved by São Rafael Hospital Research Ethics Committee and adhered to the principles of the Declaration of Helsinki. Signed informed consent for research was obtained from all subjects prior to enrollment.

Patients were excluded if they were systemically unstable because of the disease; had a prior history of significant ocular disease, ocular trauma, spherical equivalent greater than \pm 4 diopters (D), or chronic corticosteroid use; and had dense optical media opacities, prior cardiac transplantation, any neurological disease, or medication that could interfere with ANS functioning.

A complete questionnaire asking questions about family, medical, and ophthalmological evaluations was answered by all individuals. Systolic (SBP) and diastolic (DBP) blood pressure measurements were obtained during the examination and used to calculate mean arterial pressure (MAP) according to the following formula: $\mathrm{MAP}=2 / 3 \times \mathrm{DBP}+1 / 3 \times \mathrm{SBP} .^{(8)}$ All subjects underwent a standardized examination including improved corrected visual acuity, slit lamp biomicroscopy, Goldmann applanation tonometry, gonioscopy, ultrasonic pachymetry (Ocuscan RxP, Alcon Laboratories Inc.,Irvine, California, USA), fundus biomicroscopy, standard automated perimetry (SITA 24-2, Humphrey Field Analyzer II, Carl Zeiss Meditec, Dublin, CA, USA), color retinography, and optical coherence tomography (OCT) (Cirrus Optical Coherence Tomography; Carl Zeiss Meditec).

The mean value of three consecutive IOP measurements, taken between 8:00 and 11:00 a.m., was considered for the analysis. Criteria for visual field reliability included fixation losses, false positive, and false negative $<33 \%$. Retinography evaluations were performed by an experienced examiner blinded to patients' clinical data.

OCT exams with signal quality $<8$ and/or misaligned or decentered images during acquisition were not included in the study.

Mean ocular perfusion pressure (OPP) was calculated according to the following formula: $\mathrm{OPP}=2 / 3 \times \mathrm{MAP}-\mathrm{IOP}^{(8)}$.

Diagnosis of increased cup-to-disc ratio suggestive of glaucoma was based on one of the following criteria ${ }^{(9)}$ : (1) vertical cup-to-disc ratio (VCDR) $\geq 0.7$, asymmetry 
between right and left VCDR $\geq 0.15$, or neural rhythm remnant $<10 \%$ of ON diameter in the upper or lower quadrants and a consistent visual field defect with glaucoma; or (2) VCDR $\geq 0.85$ in both eyes or asymmetry between right and left VCDR $\geq 0.3$ if a reliable field test result could not be achieved.

Visual field defect was defined as consistent with glaucoma if glaucoma hemifield test was graded "outside normal limits" with a cluster of 3 contiguous points on the pattern deviation plot at the $5 \%$ level, with at least 1 at the $1 \%$ level, using the threshold test strategy with the 24-2 test pattern of the Zeiss Humphrey field analyzer ${ }^{(9)}$.

The primary outcome was designated as "ON/RNFL changes" based on the presence of $\geq 1$ of the following in at least one eye: (1) increased cup-to-disc ratio suggestive of glaucoma; (2) ON peripapillary hemorrhage, notch, and/or pallor; (3) RNFL defects visible on retinography; and (4) decreased RNFL thickness in the OCT device's software analysis as present in $<1 \%$ of the normal population in the same age group and sex.

\section{Statistical analysis}

The McNemar test and the paired t-test were used to compare proportions and means, respectively, between the chagasic and control groups. The values of only one randomly chosen eye of each individual were used in the statistical analysis. Two-tailed probability values $<0.05$ were considered statistically significant. IBM SPSS Statistics for Windows software, version 21.0 (IBM Corp., Armonk, NY, USA) was used for statistical analysis.

The mean VCDR standard deviation identified in a previous study was used to estimate that 39 individuals in each group would be required to have a power of $80 \%$ (alpha $=5 \%$ ) to detect a 0.1 difference in the VCDR between the groups. A standard deviation of 0.19 was considered in the case group and 0.15 in the control group, an intracluster correlation between both eyes of the same subject of 0.85 , and a significance level of $0.05 \%$.

\section{RESULTS}

Overall, 41 chagasic patients and 41 age- and sex-matched controls were enrolled in this study. The patients' primary characteristics are shown in table 1 .

The most commonly used medications in both groups were angiotensin II receptor antagonists, followed by $\beta$-blockers and hydrochlorothiazide in the Chagas group and hydrochlorothiazide and calcium channel blockers in the control group as listed in table 2 .
In the Chagas group, 15 patients (36.6\%) presented the cardiac disease form and CHF, 14 (34.1\%) presented the cardiac disease form without CHF, and 12 (29.3\%) presented the indeterminate form.

Evaluation of echocardiographic results in patients with Chagas disease is shown in table 3 . Heart rate variability was $118 \pm 41$ in chagasic patients with CHF, 137 \pm 21 in chagasic patients without $\mathrm{CHF}$, and $125 \pm 22$ in chagasic patients with indeterminate form $(p=0.32)$.

Ophthalmologic examination results are summarized in table 4.

Gonioscopy examinations showed no cases of angular narrowing.

The Chagas group presented 24 patients (59\%) with ON/RNFL changes versus 7 (17\%) in the control group $(p=0.01)$.

An increased cup-to-disc ratio suggestive of glaucoma was seen in 13 patients $(31.7 \%)$ in the Chagas group and $2(4.9 \%)$ in the control group $(p=0.003)$.

Table 1. Clinical characteristics

\begin{tabular}{lccc}
\hline & Chagas group & Control group & P value \\
\hline $\mathrm{N}$ & 41 & 41 & \\
Age (years) & $59.4 \pm 8.3$ & $59.3 \pm 8.5$ & NA \\
Female & $26(63.4 \%)$ & $26(63.4 \%)$ & NA \\
\hline Arterial hypertension & $32(78.0 \%)$ & $16(39.0 \%)$ & $0.002 *$ \\
Diabetes Mellitus & $4(9.3 \%)$ & $1(2.4 \%)$ & 0.380 \\
Stroke report & $4(9.3 \%)$ & $1(2.4 \%)$ & 0.360 \\
Systolic blood pressure (mmHg) & $136 \pm 22.0$ & $140 \pm 20.7$ & 0.350 \\
Diastolic blood pressure (mmHg) & $83 \pm 13.3$ & $84 \pm 12.5$ & 0.600 \\
Mean blood pressure (mmHg) & $101 \pm 15.5$ & $103 \pm 14.4$ & 0.470 \\
Heart rate (bpm) & $61 \pm 10.6$ & $75 \pm 10.5$ & 0.000 \\
\hline
\end{tabular}

$\mathrm{NA}=$ not applicable; ${ }^{*} \mathrm{P}$ value calculated with paired t-test and McNemar test.

Table 2. Medications used

\begin{tabular}{lcc}
\hline & Chagas group n (\%) & Control group n (\%) \\
\hline Angiotensin receptor antagonist & $21(51.2)$ & $12(29.3)$ \\
$\beta$-blockers & $20(48.8)$ & $2(4.9)$ \\
ACE Inhibitors & $9(21.9 \%)$ & $2(4.9 \%)$ \\
Calcium channel blockers & $3(7.3 \%)$ & $5(12.2 \%)$ \\
Digoxin & $2(4.9 \%)$ & 0 \\
Anticoagulants & $7(17.1 \%)$ & $1(2.4 \%)$ \\
Diuretics & & $6(14.6 \%)$ \\
Hydrochlorothiazide & $18(43.9 \%)$ & 0 \\
Spironolactone & $6(14.6 \%)$ & 0 \\
Furosemide & $9(21.9 \%)$ & $6(14.6 \%)$ \\
\hline Others & $10(24.4 \%)$ & \\
\hline ACE & & \\
\hline
\end{tabular}

$\mathrm{ACE}=$ angiotensin-converting enzyme 
Table 3. Echocardiographic parameters of Chagas disease patients

\begin{tabular}{|c|c|c|c|c|}
\hline & Cardiac form with $\mathrm{CHF}$ & Cardiac form without CHF & Indeterminate form & $P$ value \\
\hline Left ventricular ejection (\%) & $38 \pm 17.9$ & $67 \pm 6.5$ & $69 \pm 7.4$ & $<0.01$ \\
\hline Left ventricular dysfunction & $0.92 \pm 0.28$ & 00.00 & 00.00 & $<0.01$ \\
\hline Left ventricular end-systolic volume (ml) & $155 \pm 90.1$ & $41 \pm 14.2$ & $39 \pm 11.9$ & $<0.01$ \\
\hline Left ventricular end-diastolic volume (ml) & $231 \pm 79.2$ & $122 \pm 27.0$ & $124 \pm 22.7$ & $<0.01$ \\
\hline Right ventricular ejection (\%) & $49 \pm 16.7$ & $59 \pm 10.0$ & $66 \pm 7.7$ & $<0.01$ \\
\hline Right ventricular end-systolic volume (ml) & $57 \pm 28.5$ & $54 \pm 29.3$ & $35 \pm 12.5$ & 0.08 \\
\hline Left ventricular end-diastolic volume (ml) & $113 \pm 37.4$ & $108 \pm 33.5$ & $102 \pm 21.8$ & 0.66 \\
\hline
\end{tabular}

*P value calculated with ANOVA.

$\mathrm{CHF}=$ chronic heart failure.

Table 4. Ophthalmologic examination results

\begin{tabular}{|c|c|c|c|}
\hline & Chagas group & Control group & $P$ value \\
\hline Corrected visual acuity & $0.89 \pm 0.24$ & $0.93 \pm 0.19$ & 0.57 \\
\hline Mean spherical equivalent (D) & $1.30 \pm 1.00$ & $1.18 \pm 1.26$ & 0.64 \\
\hline Intraocular pressure (mmHg) & $14.50 \pm 3.80$ & $13.90 \pm 3.50$ & 0.38 \\
\hline Ocular perfusion pressure, Mean (mmHg) & $52.60 \pm 10.70$ & $54.80 \pm 10.6$ & 0.31 \\
\hline Central corneal thickness, Mean $(\mu)$ & $519.90 \pm 35.40$ & $520.50 \pm 32.7$ & 0.94 \\
\hline Vertical cup-to-disc ratio, Mean & $0.59 \pm 0.20$ & $0.48 \pm 0.16$ & $0.004^{*}$ \\
\hline Horizontal cup-to-disc ratio, Mean & $0.53 \pm 0.19$ & $0.45 \pm 0.14$ & $0.020^{*}$ \\
\hline
\end{tabular}

* P value calculated with paired t-test

Retinography showed that RNFL defects were detected in five eyes of four chagasic patients and in one control eye. Peripapillary hemorrhage was observed in three eyes of three chagasic patients and in none of the controls. Neural rim notch was observed in three eyes of two chagasic patients and in none of the controls. ON pallor was observed in three eyes of two chagasic patients and in none of the controls; one patient presented localized temporal pallor in both ONs, whereas the other had diffuse ON pallor in one eye (Figure 1).

Reliable visual field testing was possible in 61 eyes of the chagasic patients and 63 eyes of the controls. Mean deviation was -6.47 (5.35) $\mathrm{dB}$ in the chagasic patients and -3.60 (5.27) $d B$ in the controls $(p=0.01)$. Mean pattern deviation was 4.72 (3.5) $\mathrm{dB}$ in the Chagas group and $3.22(2.57) d B$ in the control group $(p=0.03)$.

Mean values of OCT measurements are summarized in table 5.

Figure 2 shows a comparison between clinical forms in patients with a positive primary outcome in the chagasic and control groups.

\section{DISCUSSION}

This was the first study to demonstrate the occurrence of ON/RNFL changes in chronic chagasic patients.
Alterations in ON/RNFL included ON pallor, ON changes suggestive of glaucoma, peripapillary hemorrhage, presence of notch, RNFL defect on retinography, and/or decrease in peripapillary RNFL thickness detected on OCT. Quantitative differences in data obtained from OCT measurements showed greater cup-to-disc ratio, lower neural rim arealower average decrease in RNFL thickness in the Chagas group. ON/RNFL changes were more significant in patients with Chagas disease and heart failure than in those with cardiac form without left ventricular dysfunction and those with the indeterminate form.

Inflammatory reaction due to T. cruzi infection was identified as a possible prompter of several ocular changes in the acute phase of the disease such as papillary edema, retinal hemorrhage, posterior uveitis, iridocyclitis, and glaucoma ${ }^{(4)}$. To our knowledge, no studies in the literature have evaluated the long-term prevalence and repercussions of these manifestations in the ON/RNFL of chagasic patients.

Infectious optic neuropathies often develop with sequelae in the ON/RNFL and range from slight decreases in average RNFL thickness to ON atrophy with marked decrease in visual acuity ${ }^{(10)}$. Many cases of infectious uveitis are related to transient increases in IOP that generate diffuse and localized losses in RNFL. Though 


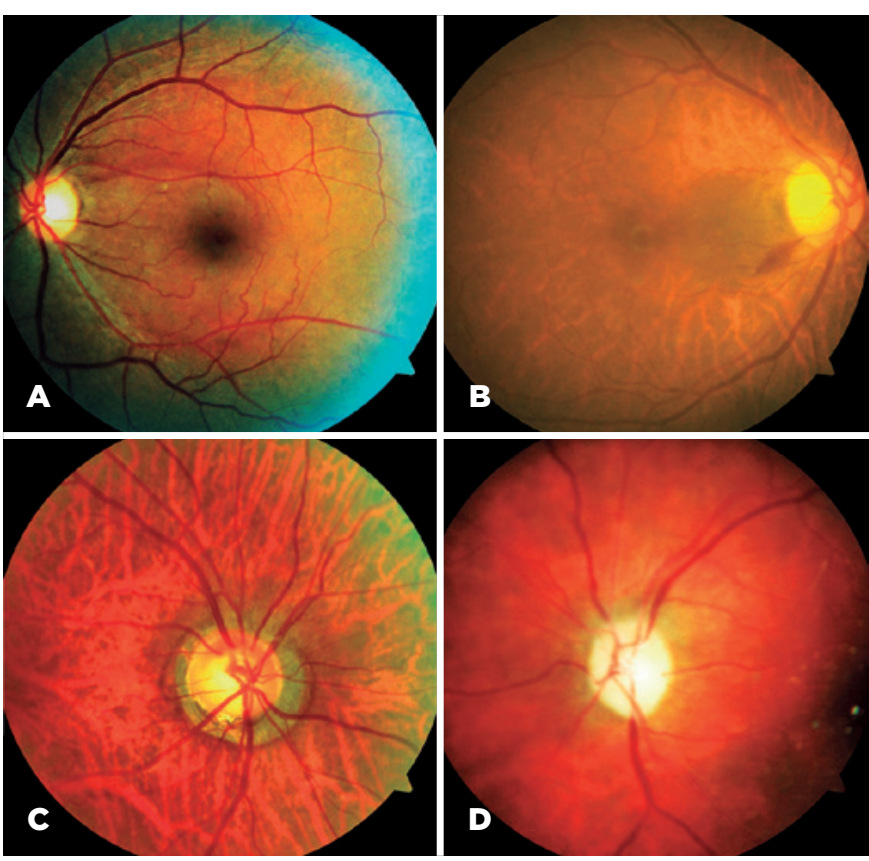

Figure 1. Chagasic patients' retinographies. A) Focal retinal nerve fiber layer defects, B) peripapillary hemorrhage, C) inferior notch of the neural rim, and D) diffuse optic nerve pallor.

Table 5. OCT measurements of the optic nerve and retinal nerve fiber layer

\begin{tabular}{lrcc}
\hline & Chagas group & Control group & P value \\
\hline Rim area $\left(\mathrm{mm}^{2}\right)$ & $1.23 \pm 0.19$ & $1.38 \pm 0.23$ & $0.003^{*}$ \\
\hline Disc area & $1.94 \pm 0.43$ & $1.92 \pm 0.40$ & 0.85 \\
Average cup-to-disc ratio & $0.56 \pm 0.14$ & $0.48 \pm 0.17$ & $0.02^{*}$ \\
\hline Vertical cup-to-disc ratio & $0.54 \pm 0.14$ & $0.46 \pm 0.16$ & $0.03^{*}$ \\
Cup volume $\left(\mathrm{mm}^{2}\right)$ & $0.21 \pm 0.15$ & $0.16 \pm 0.18$ & 0.10 \\
Average RNFL thickness $(\mu \mathrm{m})$ & $89.00 \pm 9.70$ & $94 \pm 10.6$ & $0.02^{*}$ \\
$\begin{array}{l}\text { RNFL symmetry } \\
\text { Average RNFL superior }\end{array}$ & $81.00 \pm 13.40$ & $85 \pm 10.3$ & 0.16 \\
thickness $(\mu \mathrm{m})$ & $109.00 \pm 17.50$ & $117 \pm 18.1$ & $0.04^{*}$ \\
$\begin{array}{l}\text { Average RNFL nasal } \\
\text { thickness }(\mu \mathrm{m})\end{array}$ & $71.00 \pm 9.40$ & $71 \pm 10.8$ & 0.84 \\
$\begin{array}{l}\text { Average RNFL inferior } \\
\text { thickness }(\mu \mathrm{m})\end{array}$ & $113.00 \pm 16.80$ & $122 \pm 18.4$ & $0.03^{*}$ \\
$\begin{array}{l}\text { Average RNFL temporal } \\
\text { thickness }(\mu \mathrm{m})\end{array}$ & $60.00 \pm 14.40$ & $65 \pm 12.3$ & 0.14 \\
\hline
\end{tabular}

*P value calculated with paired t-test.

$\mathrm{RNFL}=$ retinal nerve fiber layer.

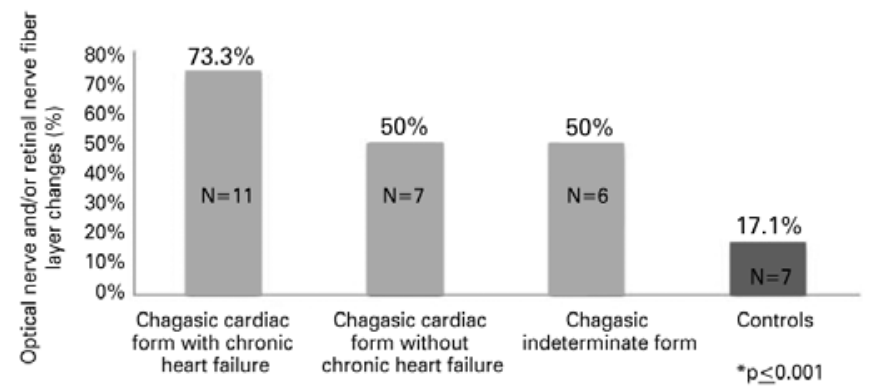

Figure 2. Comparison between clinical forms in patients who presented optic nerve/retinal nerve fiber layer changes. these losses may not be progressive, they cause irreversible damage to the ON/RNFL.

Some studies have reported on systemic inflammation secondary to Chagas disease, demonstrating that vascular endothelial injury is associated with an increase in inflammatory markers, vasospasm, and reduction in blood flow $^{(11)}$. These mechanisms of endothelial dysfunction may play an important role in the physiopathology of ophthalmic complications ${ }^{(12)}$. Some studies have demonstrated that increased ET-1 and cytokine synthesis favors vasculopathy in T. cruzi infection ${ }^{(11)}$. In experimental models, chronic ET-1 administration was associated with glaucoma-like neuropathy regardless of IOP changes $^{(13)}$.

Severity of cardiac dysfunction in Chagas patients appears to have potentiated the ON/RNFL changes since they were more prominent in the heart failure group. Heart failure has been linked to ischemic optic neuropathies and, more recently, to glaucomatous optic neuropathies ${ }^{(14)}$. A study evaluating color Doppler examination of the ophthalmic artery in heart failure patients and controls observed lower diastolic velocity and higher resistance index in those with $\mathrm{CHF}$, probably reflecting the presence of orbital vasoconstriction in response to low cardiac output $^{(15)}$. The influence of these findings on ON structure and function is still under investigation.

In the present study, mean OPP did not differ between groups. Heterogeneity of the cardiovascular condition in the chagasic group may explain these results, which differ from those observed in studies evaluating only patients with CHF and controls without heart disease $\mathrm{e}^{(7)}$. Despite this, it is important to note that OPP, MAP, and IOP are subject to variability in $24 \mathrm{~h}$, and previous studies have shown that evaluation of variability versus isolated measures may be more relevant to ON/RNFL lesions $^{(16)}$.

ANS dysfunction in chagasic patients may have contributed to the results of the present study. ANS dysfunction is observed in various clinical manifestations of Chagas disease, even in the indeterminate form ${ }^{(17)}$. Mild autonomic dysfunction typically occurs in Chagas' indeterminate form with borderline electrocardiogram abnormalities; the most severe disturbances occur in the cardiac and digestive forms ${ }^{(18)}$. Studies evaluating eye SNA dysfunction have shown that IOP level can be partially controlled by the ANS. Patients with ANS dysfunction present greater variation in IOP levels, which, combined with greater instability in blood flow regulation, probably contribute more to ON lesions than the IOP level itself ${ }^{(19)}$. 
The current study demonstrated a $17 \%$ prevalence of neuro-ophthalmological alterations between the controls. However, if only retinography and visual field were considered for analysis - complementary methods traditionally used in large population studies to evaluate the ON and nerve fiber layer ${ }^{(20,21)}$ - only two control patients (4.9\%) with alterations would have been considered. Both patients were classified as cup-to-disc ratio suggestive of glaucoma. This result is compatible with the literature describing a $3.4 \%$ prevalence of glaucoma in southern Brazil ${ }^{(22)}$.

Although previous studies have demonstrated lower IOP among patients with Chagas disease ${ }^{(23)}$, no difference in mean IOP was found between the Chagas and control patients in the present study. This finding may be related to interference from the use of systemic medications, an insufficient number of participants to detect the difference between groups, or the IOP variability itself.

This study presented some limitations. As a cross-sectional study, it cannot be determined whether the changes found in NO/RNFL are sequelae of an acute neural lesion in the acute infectious period of Chagas disease or if they are signs of a progressive neuropathy.

This was the first study to identify relevant NO/RNFL changes in patients with Chagas disease. Despite continued efforts to eradicate it, Chagas disease affects a significant part of the world's population. In view of the results demonstrated in the present study, the need for ophthalmologic examination, including a careful evaluation of NO/RNFL, in the follow-up routine of chagasic patients is evident.

\section{REFERENCES}

1. Carvalheiro JR, Azevedo N, Araujo-Jorge TC, Lannus-Vieira J, Soeiro MN, Klein L. Clássicos em doença de Chagas: histórias e perspectivas. Rio de Janeiro: Fiocruz; 2009.

2. Hotez PJ, Molyneux DH, Fenwick A, Kumaresan J, Sachs SE, Sachs JD, et al. Control of neglected tropical diseases. N Engl J Med. 2007; 357(10):1018-27.

3. Romaña C. Acerca de un sintoma inicial de valor para el diagnóstico de forma aguda de la enfermedad de Chagas. La conjuntivitis esquizotripanósica unilateral (Hipótesis sobre puerta de entrada conjuntival de la enfermedad). Public Mepra. 1935;22:16-28.

4. Berberian G, Rosanova MT, Kaldzielski C, Paulin P, Castro G, Galina L. Ocular involvement in congenital Chagas disease. Arch Argent Pediatr. 2013;111(3):e78-81. Spanish.

5. Idiaquez J. Parasympathetic denervation of the iris in Chagas' disease. Clin Auton Res. 1992;2(4):277-9.
6. Luna JD, Sonzini EE, Díaz HD, losa DJ, Juárez CP. Anomalous intraocular pressure changes in Chagas' disease elicited by postural test. Int Ophthalmol. 1996-1997;20(6):329-32.

7. Meira-Freitas D, Melo LA Jr, Almeida-Freitas DB, Paranhos A Jr. Glaucomatous optic nerve head alterations in patients with chronic heart failure. Clin Ophthalmol. 2012;6:623-9.

8. Gherghel D, Orgül S, Gugleta K, Gekkieva M, Flammer J. Relationship between ocular perfusion pressure and retrobulbar blood flow in patients with glaucoma with progressive damage. Am J Ophthalmol. 2000;130(5):597-605.

9. Foster PJ, Buhrmann R, Quigley HA, Johnson GJ. The definition and classification of glaucoma in prevalence surveys. Br J Ophthalmol. 2002;86(2):238-42.

10. Kahloun R, Abroug N, Ksiaa I, Mahmoud A, Zeghidi H, Zaouali S, et al. Infectious optic neuropathies: a clinical update. Eye Brain. 2015;7:59-81.

11. Tanowitz HB, Huang H, Jelicks LA, Chandra M, Loredo ML, Weiss LM, et al. Role of endothelin 1 in the pathogenesis of chronic chagasic heart disease. Infect Immun. 2005;73(4):2496-503.

12. Salvatore S, Vingolo EM. Endothelin-1 role in human eye: a review. J Ophthalmol. 2010;2010:354645.

13. Orgül S, Cioffi GA, Wilson DJ, Bacon DR, Van Buskirk EM. An endothelin-1 induced model of optic nerve ischemia in the rabbit. Invest Ophthalmol Vis Sci. 1996;37(9):1860-9.

14. Flammer J, Konieczka K, Bruno RM, Virdis A, Flammer AJ, Taddei S. The eye and the heart. Eur Heart J. 2013;34(17):1270-8.

15. Almeida-Freitas DB, Meira-Freitas D, Melo LA Jr, Paranhos A Jr, lared W, Ajzen S. Color Doppler imaging of the ophthalmic artery in patients with chronic heart failure. Arq Bras Oftalmol. 2011; 74(5):326-9.

16. Kwon J, Lee J, Choi J, Jeong D, Kook MS. Association between nocturnal blood pressure dips and optic disc hemorrhage in patients with normal-tension glaucoma. Am J Ophthalmol. 2017;176:87-101.

17. Consolim-Colombo FM, Filho JA, Lopes HF, Sobrinho CR, Otto ME, Riccio GM, et al. Decreased cardiopulmonary baroreflex sensitivity in Chagas' heart disease. Hypertension. 2000;36(6):1035-9.

18. Junqueira LF Jr. Insights into the clinical and functional significance of cardiac autonomic dysfunction in Chagas disease. Rev Soc Bras Med Trop. 2012;45(2):243-52.

19. Pasquale LR. Vascular and autonomic dysregulation in primary open-angle glaucoma. Curr Opin Ophthalmol. 2016;27(2):94-101.

20. Gordon MO, Beiser JA, Brandt JD, Heuer DK, Higginbotham EJ, Johnson CA, et al. The Ocular hypertension treatment study: baseline factors that predict the onset of primary open-angle glaucoma. Arch Ophthalmol. 2002;120(6):714-20.

21. Leske MC, Connell AM, Schachat AP, Hyman L. The Barbados Eye Study. Prevalence of open angle glaucoma. Arch Ophthalmol. 1994;112(6):821-9.

22. Sakata K, Sakata LM, Sakata VM, Santini C, Hopker LM, Bernardes $\mathrm{R}$, et al. Prevalence of glaucoma in a South Brazilian population: projeto Glaucoma. Invest Ophthalmol Vis Sci. 2007;48(11):4974-9.

23. Prata JA, Prata JA Jr, Prata A, Macedo V, Castro CN. Pressão intraocular na forma crônica da doença de Chagas. Arq Bras Oftalmol. 1997; 60(1):99-102. 